\title{
Motivasi Belajar Siswa di Madrasah Aliyah Annur Nusa Kecamatan Kahu Kabupaten Bone
}

\author{
Mulia Reski, Risma Niswaty, Sirajuddin Saleh \\ Pendidikan Administrasi Perkantoran, Universitas Negeri Makassar \\ Email: risma.niswaty@unm.ac.id
}

\begin{abstract}
ABSTRAK
Peneitian ini bertujuan untuk mengetahui motivasi belajar siswa pada Madrasah Aliyah Annur Nusa Kecamatan Kahu Kabupaten Bone. Penelitian ini merupakan penelitian deskriptif kuantitatif. Populasi penelitian ini sebanyak 173 siswa dan jumlah sampel sebanyak 44 siswa. Teknik pengumpulan data yang digunakan adalah observasi, angket, wawancara dan dokumentasi. Teknik analisis data yang digunakan yaitu analisis deskriptif. Hasil penelitian menujukkan bahwa motivasi belajar siswa di Madrasah Aliyah Annur Nusa kecamatan Kahu Kabupaten Bone tergolong tinggi. Dilihat dari hasrat dan keinginan berhasil tergolong sangat tinggi, dorongan dan kebutuhan dalam belajar tergolong tinggi, harapan dan cita-cita tergolong sangat tinggi, penghargaan tergolong tinggi, kegiatan yang menarik dalam belajar tergolong tinggi dan lingkungan belajar yang kondusif tergolong tinggi.
\end{abstract}

Kata kunci: Motivasi Belajar, Siswa

\begin{abstract}
This study aims to determine students' learning motivation in Madrasah Aliyah Annur Nusa, Kahu District, Bone Regency. This research is quantitative descriptive. The population of this study was 173 students and the number of samples was 44 students. Data collection techniques used are observation, questionnaires, interviews and documentation. Data analysis technique used is descriptive analysis. The results showed that students' learning motivation at Annur Nusa Madrasah Aliyah in Kahu subdistrict, Bone Regency was high. Judging from their desires and desires, success is classified as very high, encouragement and needs in learning are high, expectations and ideals are very high, awards are high, interesting activities in learning are high and conducive learning environment is high.
\end{abstract}

Keywords: Learning Motivation, Students

\section{PENDAHULUAN}

Pendidikan merupakan kebutuhan hidup setiap manusia karena disadari bahwa tidak ada satu orang yang dilahirkan membawa ilmu.(Behrman, 2010; D'Ippolito, Miozzo, \& Consoli, 2014; Howson et al., 2018; Jarcău, 2014; Turina, Lutsenko, \& Oleynikova, 2015; van Santen, 2014) Dengan adanya ilmu yang terbentuk melalui pendidikan maka terwujudlah pengembangan potensi dirinya untuk kecerdasan, kepribadian, akhlaq mulia dan terampil yang diperlukan dirinya dalam masyarakat. Ermawati (2017) mengutarakan bahwa "pendidikan 
adalah hidup. Pendidikan adalah segala pengalaman belajar yang berlangsung dalam segala lingkungan dan sepanjang hidup".

Pendidikan juga merupakan segala pengaruh yang diupayakan oleh sekolah terhadap anak dan remaja yang diserahkan kepadanya agar mempunyai kemampuan dan kesadaran penuh terhadap hubungan dan tugas sosial mereka. Dengan demikian, pengajaran di sekolah haruslah dikelolah secara terprogram berdasarkan prosedur ilmiah. Dalam hal itu, pendidikan yang dimaksud adalah proses pembelajaran yang dilakukan oleh pendidik dan peserta didik yang saling berinteraksi dan saling bertukar informasi dengan membahas pelajaran tertentu yang menghasilkan hasil belajar.

Pada perkembangan ilmu dan teknologi yang semakin hebat maka muncullah persaingan dibidang pendidikan. Cara untuk meningkatkan mutu pendidikan adalah dengan memperbaiki segala aspek pendidikan yang meliputi SDM, sarana dan prasarana dan Kurikulum. Proses pendidikan atau kegiatan belajar-mengajar pun hendaknya seorang pendidik memiliki banyak gabungan dari berbagai pengalaman belajar. Seperti yang dikemukakan oleh Ermawati (2017) ada tiga hal yang dapat dilakukan yaitu "menggunakan berbagai sumber belajar, guru memposisikan diri sebagai contoh, fasilitator dan motivator, menggunakan berbagai alat bantu mengajar". Hal terpenting adalah cara seorang guru atau pendidik untuk memotivasi peserta didik dalam menumbuhkan semangat belajar. Siswa akan berhasil belajarnya jika dalam dirinya ada keinginan untuk belajar yakni motivasi dalam belajar(M. S. Saggaf et al., 2018; S. Saggaf, Salam, Kahar, \& Akib, 2014).

Motivasi belajar merupakan pendorong untuk melakukan suatu aktivitas belajar untuk mencapai suatu tujuan yaitu adanya perubahan dari hasil belajar tersebut. Sehubungan dengan itu, siswa tidak termotivasi apabila ada kendala, baik dalam diri sendiri maupun dalam lingkungan sekolah. Apabila siswa dalam keadaan sehat maka akan menyebabkan siswa tersebut bersemangat dalam belajar dan mampu menyelesaikan tugas dengan baik. Kebalikan dengan siswa yang sedang sakit maka siswa tersebut tidak bersemangat dalam belajar. Disamping itu, lingkungan siswa yang berupa tempat tinggal, keadaan alam dan pergaulan juga mendukung adanya semangat belajar. Misalnya, dalam lingkungan yang aman, tentram, nyaman dan indah maka siswa akan lebih semangat dan termotivasi untuk belajar. Motivasi merupakan faktor penyebab belajar yang dapat memperlancar aktivitas belajar, sehingga siswa yang termotivasi tinggi dalam belajar memungkinkan akan memperoleh hasil belajar yang tinggi pula, artinya semakin tinggi motivasinya maka semakin tinggi usaha dan upaya yang dilakukan sehingga semakin tinggi hasil yang diperolehnya (Abdullah \& Yih, 2014; Barak, Watted, \& Haick, 2016; Fischer \& Sliwka, 2018; Gegenfurtner \& Vauras, 2012; Kashif, Ayyaz, Raza, \& Hamid, 2013; McComb \& Kirkpatrick, 2016).

Berdasarkan pengamatan penulis tentang motivasi belajar siswa yang dilakukan di Madrasah Aliyah Annur Nusa padi hari Senin tanggal 22 Januari 2018, ketika guru menerangkan masih banyak siswa yang tidak fokus pada saat pembelajaran berlangsung dan bahkan ada beberapa siswa yang tidak menyelesaikan tugas yang diberikan oleh guru tersebut dengan alasan kurang memahami, dan dengan waktu yang sama pada saat jam pelajaran berlangsung banyak siswa yang keluar kelas atau tidak belajar karena guru yang bersangkutan tidak berada di kelas. Maka dari itu, penulis dapat memahami bahwa kurangnya motivasi belajar siswa ditandai dengan tidak semangat dan tidak fokus dalam belajar sehingga tidak 
memahami tugas yang diberikan dan banyaknya siswa keluar kelas yang lebih memilih berkumpul di depan kelas dan sebagian siswa yang lainnya ke kantin dengan alasan guru pada saat itu tidak berada di kelas. Dalam hal ini, penulis bermaksud melakukan penelitian yang bertujuan untuk mengetahui lebih dalam tentang Motivasi Belajar Siswa di Madrasah Aliyah Annur Nusa Kecamatan Kahu Kabupaten Bone.

\section{METODE}

Penelitian ini menggunakan pendekatan kuantitatif dengan jenis penelitian deskriptif yang dirancang untuk mengukur motivasi belajar siswa (Creswell, 2014). Penelitian ini menggunakan teknik analisis deskriptif dengan menggunakan tabel frekuensi dan persentase. Adapun populasi dalam penelitian adalah siswa di Madrasah Aliyah Annur Nusa Kecamatan Kahu Kabupaten Bone sebanyak 173 siswa, dengan menggunakan teknik Simple Random Sampling. Dengan menggunakan penarikan sampel sebesar 15\% dari jumlah populasi atau sama dengan 44 siswa mulai dari kelas $\mathrm{X}$ dan XI. Pengumpulan data dalam penelitian ini menggunakan teknik angket, wawancara, observasi dan dokumentasi. Data yang terkumpul akan dianalisis dengan menggunakan tabel frekuensi dan persentase.

\section{HASIL PENELITIAN DAN PEMBAHASAN}

\section{Hasil Penelitian}

Adapun dalam penelitian data ini menggunakan metode frekuensi dan persentase. Adapun variabel motivasi belajar siswa diperoleh pada tabel 1 .

Tabel 1 . Indikator variavel mutivasi Belajar

\begin{tabular}{|c|c|c|c|c|c|}
\hline No & Indikator & (n) & $(\mathbf{N})$ & $\%$ & Kategori \\
\hline 1 & Hasrat dan keinginan berhasil & 1558 & 1760 & 88.52 & $\begin{array}{l}\text { Sangat } \\
\text { Tingoi }\end{array}$ \\
\hline 2 & Dorongan dan kebutuhan dalam belajar & 772 & 1100 & 70,18 & Tinggi \\
\hline 3 & Harapan dan cita-cita & 834 & 880 & 94,77 & $\begin{array}{l}\text { Sangat } \\
\text { Tinggi }\end{array}$ \\
\hline 4 & Penghargaan & 1161 & 1540 & 75,38 & Tinggi \\
\hline 5 & Kegiatan yang menarik dalam belajar & 1228 & 1540 & 79,74 & Tinggi \\
\hline 6 & $\begin{array}{l}\text { Lingkungan belajar yang kondusif sehingga } \\
\text { dapat belajar dengan baik }\end{array}$ & $\frac{1310}{6863}$ & $\frac{1980}{8800}$ & $\frac{66,16}{47476}$ & $\frac{\text { Tinggi }}{\text { Tingoi }}$ \\
\hline
\end{tabular}

Gambaran umum motivasi belajar siswa setelah dilakukan pengumpulan data dengan mengacu pada 6 indikator yaitu: 1) Hasrat dan keinginan berhasil, di Madrasah Aliyah Annur Nusa berada pada kategori sangat tinggi motivasi belajarnya dengan nilai yang diperoleh sebesar 1558 serta nilai ideal 1760 dan dipersentasikan menjadi 88,52 persen, 2) Dorongan dan kebutuhan dalam belajar, pada Madrasah Aliyah Annur Nusa berada pada kategori tinggi dalam motivasi belajarnya dengan nilai 772 serta nilai ideal sebesar 1100 lalu kemuudian dipersentasekan menjadi 70,18 persen, 3) Harapan dan cita-cita, pada Madrasah Aliyah Annur 
Nusa berada pada kategori sangat tinggi dalam motivasi belajarnya dengan nilai yang diperoleh sebesar 834 dengan nilai ideal sebesar 880 dan dipersentasekan menjadi 94,77 persen, 4) Penghargaan, pada Madrasah Aliyah Annur Nusa berada pada kategori tinggi dalam motivasi belajarnya dengan nilai yang diperoleh sebesar 1161 dan nilai ideal sebesar 1540 lalu kemudian dipersentasekan menjadi 75,38 persen, 5) Kegiatan yang menarik dalam belajar, pada Madrasah Aliyah Annur Nusa berada pada kategori tinggi dalam motivasi belajarnya dengan nilai 1228 sera nilai ideal sebesar 1540 dan nilai dipersentasekan menjadi 79,74 persen, dan 6) Kondisi belajar yang kondusif, pada Madrasah Aliyah Annur Nusa berada pada kategori tinggi dalam motivasi belajarnya dengan nilai 1310 serta nilai ideal sebesar 1980 dan nilai yang dipersentasekan sebesar 66,16 persen.

\section{Pembahasan}

Berdasarkan hasil analisis di atas, dapat disimpulkan bahwa motivasi belajar siswa di Madrasah Aliyah Annur Nusa Kecamatan Kahu Kabupate Bone berada dalam kategori tinggi. Hal ini menunjukkan bahwa dari ke enam indikator yang diteliti ternyata pada umumnya menyatakan tinggi atau motivasi belajarnya yang tinggi. Dari ke enam indikator tersebut dapat diuraikan sebagai berikut.

1. Hasrat dan keinginan berhasil

Unsur yang pertama yaitu hasrat dan keinginan berhasil yang menunjukkan kategori sangat tinggi dengan persentase $88,52 \%$. Hal ini dilihat peserta didik selalu semangat belajar dengan mengikuti mata pelajaran dari awal pembelajaran sampai akhir pembelajaran, selalu mengerjakan tugas dengan tepat waktu, sering merasa cemas apabila tidak mengerjakan tugas dengan tepat waktu, selalu merasa senang jika mendapat nilai tinggi, selalu mempertahankan nilai tinggi dengan belajar lebih giat.

\section{Dorongan dan kebutuhan dalam belajar}

Unsur yang kedua menunjukkan kategori tinggi dengan persentase 70,18 \%. Hal ini dapat dilihat peserta didik sering mencari materi tambahan untuk menambah pengetahuan, selalu memanfaatkan teknologi atau perpustakaan untuk menambah pengetahuan, guru sering memberikan hukuman jika melakukan kesalahan di Sekolah, peserta didik tidak pernah merasa keberatan apabila diberikan hukuman, dan siswa tidak pernah mengulangi kesalahan yang lalu.

\section{Harapan dan cita-cita}

Unsur yang ke tiga yaitu harapan dan cita-cita yang menunjukkan kategori sangat tinggi dengan persentase $94,77 \%$. Hal ini dilihat dari peserta didik yang selalu ingin mendapatkan prestasi di Sekolah, selalu mempertahankan prestasi yang dimiliki, tujuan belajar selalu ingin mendapatkan kebanggan orang tua dan sekolah. 
Mulia Reski, Risma Niswaty, Sirajuddin Saleh; Motivasi Belajar Siswa... $\mid 29$

\section{Penghargaan}

Unsur yang ke empat yaitu penghargaan yang menunjukkan kategori tinggi dengan persentase $75,38 \%$. Hal ini dilihat bahwa peserta didik sering mendapat pujian dari guru dan selalu mendapat pujian dari orang tua, peserta didik yang mendapat pujian selalu berpengaruh dalam meningkatkan motivasi belajarnya, guru dan orang tua jarang memberikan hadiah kepada peserta didik yang mendapat nilai yang baik, peserta didik selalu merasa lebih semangat belajar apabila diberikan hadiah oleh guru dan orang tua.

\section{Kegatan belajar yang menarik dalam belajar}

Unsur yang ke lima yaitu kegiatan belajar yang menarik yang menunjukkan kategori tinggi dengan persentase $79,74 \%$. Hal ini dilihat peserta didik selalu merasa lebih giat belajar apabila suasana belajar yang menyenangkan baik dalam lingkungan Sekolah maupun di Rumah, guru jarang menyampaikan materi dengan tidak membosankan, peserta didik selalu merasa semangat belajar apabila guru menyampaikan materi dengan tidak membosankan, peserta didik selalu lebih semangat belajar apabila guru menerapkan metode diskusi, siswa jarang menginginkan untuk menjadi ketua kelompok apabila guru membentuk kelompok diskusi, dan siswa sering aktif dalam forum diskusi.

\section{Lingkungan belajar yang kondusif, sehingga dapat belajar dengan baik}

Unsur yang ke enam yaitu lingkungan belajar yang kondusif, sehingga dapat belajar dengan baik menunjukkan kategori tinggi dengan $66,16 \%$. Hal ini dilihat peserta didik kadangkadang merasa terganggu apabila lingkungan bising, peserta didik jarang merasa semangat apabila lingkungan belajar bising, kondisi belajar yang nyaman selalu membuat peserta didik dapat belajar dengan baik, peserta didik selalu merasa semangat belajar apabila lingkungan Sekolah nyaman, peserta didik sering mengeluh apabila kepanasan di dalam Kelas, peserta didik jarang semangat dalam belajar apabila suhu di dalam kelas panas, fasilitas belajar selalu mempengaruhi semangat belajar peserta didik, motivasi belajar siswa jarang ditentukan dengan kelengkapan fasilitas di dalam Kelas dan siswa selalu menyiapkan fasilitas belajar sebelum melakukan proses belajar.

Pada penelitian sebelumnya yang dilakukan oleh Asih bahwa motivasi intrinsik yang dimiliki siswa SMPN 15 Yogyakarta adalah minat yang berasal dari diri mereka sendiri, sedanngkan motivasi ekstrinsik mereka adalah adanya pemberian nilai pada tugas dan ulangan serta adanya remedi atau perbaikan nilai, faktor yang mempengaruhi motivasi belajar siswa adalah minat, kurangnya dukungan fasilitas yang diberikan oleh orang tua juga mempengaruhi motivasi belajar siswa, kecemasan dalam suasana pembelajaran di kelas, dan teman-teman sepermainan di sekolah membawa pengaruh negatif kepada siswa lain agar mengikuti tindakan yang dapat menurunkan prestasi belajar dan upaya yang dilakukan oleh sekolah untuk meningkatkan prestasi belajar siswa antara lain memberikan angka yang objektif pada tugas harian, ulangan harian, atau ulangan umum semester, memberikan hadiah kepada siswa yang mendapatkan juara perlombaan antar kelas dan jauara kelas, guru memberikan pujian kepada 
3O| Jurnal Office, Vol. 4, No. 1, Januari-Juni 2018

siswa yang dapat menjawab pertanyaan yang diberikan pada saat pelajaran atau saat mendapatkan nilai yang memuaskan setelah ulangan atau tugas, memberikan ulangan harian untuk mengetahui seberapa paham siswa terhadap mata pelajaran yang diberikan dan sebagai evaluasi guru, memberikan hukuman berupa memberikan tugas tambahan, memberikan masukan kepada siswa yang prestasinya yang masih kurang standar dan memberikan bantuan kepada siswa yang perlu diberikan tambahan pelajaran.

Berdasakan ke enam unsur di atas dan dari penelitian terdahulu yang dilakukan oleh Asih bahwa untuk mengukur motivasi belajar siswa dapat dilihat dari indikator motivasi belajar yakni adanya hasrat dan keinginan berhasil, adanya dorongan dan kebutuhan dalam belajar, adanya harapan dan cita-cita, adanya penghargaan, adanya kegiatan menarik dalam belajar dan adanya lingkungan belajar yang kondusif, sehingga dapat belajar dengan baik. Unsur tersebut yang kemudian digunakan oleh peneliti untuk mengukur motivasi belajar siswa di Madrasah Aliyah Annur Nusa Kecamatan Kahu Kabupaten Bone

\section{SIMPULAN}

Berdasarkan uraian dan penjelasan dari hasil penelitian dan pembahasan di atas, dapat disimpulkan bahwa Motivasi Belajar Siswa di Madrasah Aliyah Annur Nusa Kecamatan Kahu Kabupaten Bone terbilang memiliki motivasi yang tinggi dalam belajar. Hal ini dilihat dari hasil yang diperoleh dari setiap indikator pada variabel ini yaitu: 1) Hasrat dan keinginan berhasil, siwa dalam motivasi belajar berada pada kategori sangat tinggi dengan persentase 88,52 persen, 2) Dorongan dan kebutuhan dalam belajar, siswa dalam motivasi belajar berada pada kategori tinggi dengan persentase 70,18 persen, 3) Harapan dan cita-cita, siswa dalam motivasi belajar berada pada kategori sangat tinggi dengan persentase 94,77 persen, 4) Penghargaan, siswa dalam motivasi belajar berada pada kategori tinggi dengan perentase 75,38 persen, 5) Kegiatan yang menarik dalam belajar, siswa dalam motivasi belajar berada pada kategori tinggi dengan persentase 79,74 persen, 6) Lingkungan belajar yang kondusif, sehingga dapat belajar dengan baik, siswa dalam motivasi belajar berada pada kategori tinggi dengan persentase 66,16 persen..

\section{DAFTAR PUSTAKA}

Abdullah, A., \& Yih, T. Y. (2014). Implementing Learning Contracts in a Computer Science Course as a Tool to Develop and Sustain Student Motivation to Learn. Procedia - Social and Behavioral Sciences, 123, 256-265. https://doi.org/https://doi.org/10.1016/j.sbspro.2014.01.1422

Barak, M., Watted, A., \& Haick, H. (2016). Motivation to learn in massive open online courses: Examining aspects of language and social engagement. Computers \& Education, 94, 4960. https://doi.org/https://doi.org/10.1016/j.compedu.2015.11.010

Behrman, J. R. (2010). Chapter 73 - Investment in Education-Inputs and Incentives*. In D. Rodrik \& M. B. T.-H. of D. E. Rosenzweig (Ed.), Handbooks in Economics (Vol. 5, hal. 4883-4975). Elsevier. https://doi.org/https://doi.org/10.1016/B978-0-444-52944-2.00011- 
Mulia Reski, Risma Niswaty, Sirajuddin Saleh; Motivasi Belajar Siswa... $\mid 31$

2

Creswell, J. w. (2014). Research Design: qualitative, quantitative, and Mix Methods Approaches (Fourth). Los Angeles, USA: Sage Publications.

D’Ippolito, B., Miozzo, M., \& Consoli, D. (2014). Knowledge systematisation, reconfiguration and the organisation of firms and industry: The case of design. Research Policy, 43(8), 1334-1352. https://doi.org/https://doi.org/10.1016/j.respol.2014.03.013

Ermawati, E. (2017). Pengaruh Kontrak Psikologis Dan Komitmen Organisasi Terhadap Kinerja Karyawan. ASSETS: Jurnal Ilmiah Ilmu Akuntansi, Keuangan dan Pajak, 1(2), 73-92.

Fischer, M., \& Sliwka, D. (2018). Confidence in knowledge or confidence in the ability to learn: An experiment on the causal effects of beliefs on motivation. Games and Economic Behavior, 111, 122-142. https://doi.org/https://doi.org/10.1016/j.geb.2018.02.005

Gegenfurtner, A., \& Vauras, M. (2012). Age-related differences in the relation between motivation to learn and transfer of training in adult continuing education. Contemporary Educational Psychology, 37(1), 33-46. https://doi.org/https://doi.org/10.1016/j.cedpsych.2011.09.003

Howson, C. P., Cedergren, B., Giugliani, R., Huhtinen, P., Padilla, C. D., Palubiak, C. S., ... McCabe, E. R. B. (2018). Universal newborn screening: A roadmap for action. Molecular Genetics and Metabolism, 124(3), 177-183. https://doi.org/https://doi.org/10.1016/j.ymgme.2018.04.009

Jarcău, M. (2014). Intercultural Education Important Component of Lifelong Learning. Procedia - Social and Behavioral Sciences, 142, 421-426. https://doi.org/https://doi.org/10.1016/j.sbspro.2014.07.704

Kashif, M., Ayyaz, M., Raza, A., \& Hamid, W. S. (2013). Business undergraduates' perceptions of motivation to learn: Empirical evidence from Pakistan. The International Journal of Management Education, 11(2), 75-84. https://doi.org/https://doi.org/10.1016/j.ijme.2013.02.002

McComb, S. A., \& Kirkpatrick, J. M. (2016). Impact of pedagogical approaches on cognitive complexity and motivation to learn: Comparing nursing and engineering undergraduate students. Nursing Outlook, 64(1), 37-48. https://doi.org/https://doi.org/10.1016/j.outlook.2015.10.006

Saggaf, M. S., Aras, M., Akib, H., Salam, R., Baharuddin, A., \& Kasmita, M. (2018). The Quality Analysis of Academic Services Based on Importance Performance Analysis (IPA).

Saggaf, S., Salam, R., Kahar, F., \& Akib, H. (2014). Pelayanan Fungsi Administrasi 
32| Jurnal Office, Vol. 4, No. 1, Januari-Juni 2018

Perkantoran Modern. Jurnal Ad'ministrare, 1(1), 20-27.

Turina, J., Lutsenko, E., \& Oleynikova, E. (2015). New Media in Daily Life of Educational Process Subjects: A Case of Khabarovsk Higher Education Institutions. Procedia - Social and Behavioral Sciences, 214, 174-182. https://doi.org/https://doi.org/10.1016/j.sbspro.2015.11.614

van Santen, J. C. M. (2014). 'Do life histories surface as time goes by?': Longitudinal anthropological research, time and feminist knowledge production. Women's Studies International Forum, 43, 22-29. https://doi.org/https://doi.org/10.1016/j.wsif.2013.07.016 